\title{
Kur'an Kıraatinde Türklere Özgü Mahalli Okuyuş Sorunu
}

\author{
MEHMET AKİF KOÇ \\ DOÇ.DR., ANKARA Ü. İLAHIYAT FAKÜLTESİ \\ koc@divinity.ankara.edu.tr
}

\begin{abstract}
Özet
Kur'an'1 evrensel kabul gören Arap tarzını umursamayarak mahalli Türk ağzıyla okuma konusundaki ısrar, Türkiye'nin diğer pek çok sorunuyla bağlantılı bir kısırdöngü haline gelmiştir. Evrensel değerlerden kaçarak bizim ve ülkemizin özel olduğunu öne sürmek, hayatın her alanına ilişkin mahalli bir duruş icat etmek eskiden bizi sadece yalnızlaştırıyordu. Ancak Dünya'nın bu kadar küçüldüğü ve küreselleşmenin sınır tanımadığı şimdilerde artık bizi komik duruma da düşürmektedir. Arapçanın fonetiği konusunda Araplara rağmen belirleyici olamayız. Yine apaçık bir Arapça ile vahyedilen Kur'an'ın nasıl okunacağını; tecvidi, ilgili sesleri ve ağız hareketlerini mevcut kitabiyattan öğrenebileceğimizi varsaymak doğru değildir. Ses kitaptan öğrenilemez. Ayrıca, ülkemizde itibar gören kıraat kitaplarının Arap âleminde bizden çok daha yaygın okutulduğu halde mahiyeti farklı iki okuyuş türünün zuhur ettiğini; belirleyicinin kitap değil, kitabı okutan hoca olduğunu neden görmezden geliyoruz? Aslında İslami ilimler içinde ses merkezli kıraat eğitiminin fem-i muhsin (uzman ağzı) arac1lığıyla verilebileceğini hicri ilk asırlardan beri bilmekteyiz. Ancak bilmediğimiz fem-i muhsinin ana vasfidır. Fem-i muhsin, kitaba dayalı geleneği devam ettirerek Kur'an kıraatine emek veren ya da onu öğretmeye ömrünü feda eden emektar bir hoca değil; gerekli eğitimi alarak doğru / otantik okuyuş melekesini kazanmış bir Arap ya da onu aratmayacak kadar ona benzeyen bir okuyuşun sahibidir.
\end{abstract}

Anahtar kelimeler: Fem-i muhsin, kıraat, $\imath$ àtÊb, tecvid

\footnotetext{
Abstract

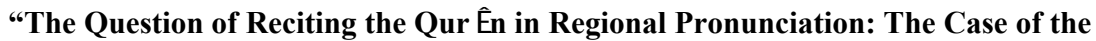
Turks"

Turkish reciters of the Qur|t̂n do not pay sufficient attention to the authentic Arabic style of pronunciation in their practice of recitation. Despite the fact that the Arabic pronunciation of the Holy Book is a worldwide practice, the Turks still insist on recit-
} 
ing the Qur|t̂n according to their regional pronunciation, i.e., universal the traditional Turkish mouth. This situation is nothing but a typical reflection of obssesive attitudes against international values observable at many levels of the Turkish society. In the past, we would stay away from universal values and claim that our country and everything that belongs to us would be distinctively special. Following this line of logic, we would make up national stances regarding every single matter in this life, though this logic would not produce any positive result but separate us from the rest of mankind. In today's world too, such obssesive attitudes lead us quite ridiculous situations in a world that has turned into, through globalization, a kind of small village. We Turks should not attempt to determine the phonetics of the Arabic language and stand against their long-lasting conventions. Neither should we claim that we can learn everything solely from books regarding the recitation of the Qur|t̂n. God has revealed the

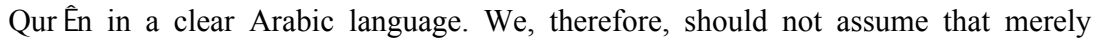
through studying the books available in the field of Qur|t̂nic studies we can acquire a complete knowledge sufficient for us to learn competently how to recite the Qur㕰, to perform the art of recitation (tajwld), to articulate the proper letters and sounds, and the like; for sounds cannot be learned just from books. Both in Turkey and Arab countries teachers and students use the same books on the styles and schools of the Qur|t̂nic recitation. Then how can we explain the result that we see two inherently different types of recitation? This result indicates that it is not the books, but the teachers that determine these types. In fact, since the earliest Islamic centuries, we know that, as a sound-based scholarly discipline, the QurÊtic recitation can be learned only from a "qualified mouth" (fem-i muÜsin), but that which we do not know is the main characteristics of this $f e m-i m u$ Ùsin. The fem-i mu Ùsin is not a person who has spent his whole life and scholarly energy on teaching the recitation of the Qur他. Rather, the real fem-i mu Usin is an Arab who has acquired the required knowledge and practise in the field, or a non-Arab who can recite the Qur战 as perfect and authentic as this Arab qualified.

Keywords: Fem-i muÙsin, Recitation of the Qur'ān, $\imath q l \hat{\mathrm{E} b}$, tajwRl,

\section{Giriş}

Kur'an, başlangıçtan beri yalnızca anlaşılan ve hayata tatbik edilen değil, aynı zamanda tilaveti ibadet telakki edilen bir metin olarak kabul görmüştür. $\mathrm{Bu}$ günkü Müslüman dünyanın önceki Müslüman nesillerden tevarüs ettiği uygulamalar göstermektedir ki, Kur'an tilaveti, namazlarda Kur'an okumanın çok ötesinde bir manayı da ihata etmekte; çok daha serbest bir ibadet türünü bizatihi "sevap kazanmak için okumayı" ifade etmektedir. Şüphesiz bunun arkasında, Kur'an metnindeki kutsiyetin ve eşsizliğin, "mana" yanında bizatihi metnin lafzında da bulunduğu inancı vardır. Bu inancı te Ùadd

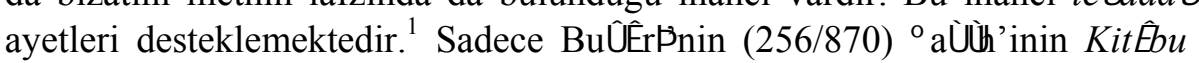

Kur'an'ın, ilahi kaynağı konusunda şüphe duyan ilk muhataplarına meydan okuması anlamına gelen bu kavram, toplam 5 ayeti doğrudan konu edinmektedir: 2:23-24, 10:38, 11:13, 17:88, 52:34. Bu ayetler, insanların ve cinlerin işbirliği yapsalar bile ne Kur'an'ın bir kısmına ne de tamamına benzer bir 
$f_{e} \tilde{N} \hat{\mathbf{E}}$ illi'l-“ ur $\hat{\mathrm{E}}$ ''na bir göz atmak bile, mezkur serbest ibadet türünün $\mathrm{Hz}$. Peygamber ve Sahâbe dönemindeki başlangıç uygulamalarını görmek bakımından yeterlidir. Söz gelimi, Hz. Peygamber'in talebi üzerine ,Abdullêh b. Mes,ød'un (32/652) sesli Kur'an okumas1, İbn Mes,ød 4:41. ayetine gelince, Hz. Peygamber'in duygulanmasi ${ }^{2}$ her ne kadar manaya vurgu yapan bir içeriğe sahipse de Hz. Peygamber'in bir sahâbîden Kur'an dinlemeyi istemesi şüphesiz ki bu geleneğin başlamasına güçlü bir destek vermiştir.

“ ur tbÙ (671/1272) tefsirinin giriş kısmında, "insan sesinin mi Kur'an ile süsleneceği” yoksa "Kur'an'ın mı insan sesiyle güzelleștirileceğgi", ilgili rivayetin farklı tarikleri üzerinden tartışmaya açılmaktadır. ${ }^{3}$ Yine " urtubÙ tefsirinde Mısırlı kârîlerin para karşıllı̆̆ Kur'an okumalarını eleştirmektedir. ${ }^{4}$ $\mathrm{Bu}$ eleştiri, hem bu tilavet geleneğinin ne kadar yaygın olduğunu göstermekte, hem de o dönemin sosyal yapısına dair konumuzla ilgili önemli bir bilgiyi getirmektedir.

Kur'an kelimelerinin telaffuz şekillerini ve eda yollarını müstakil bir disiplin olarak konu edinen Kuraat ilmi, sesli Kur'an tilavetini de tabii ki ele almaktaydı. Hicri II. yüzyılın başından itibaren kıraat ilminin tedris edilmeye başlandığını bilmekteyiz. Ne var ki, bu makalenin konusu kıraat ilminin teknik konularının özellikle de literatür bilgilerinin değerlendirilmesi değildir. Çok daha özel ve pratik alanı doğrudan ilgilendiren bir sorun üzerine odaklanmayı hedeflemekteyiz: Ülkemizdeki Kur'an okuma tarzının diğer Müslüman ülkelerden özellikle de Arap ülkelerinden ayrılan yönleri, bunun sebepleri ve sonuçları hakkında söz söylemeyi amaçlamaktayız. Konuyu, sorunu gözler önüne seren bir tecrübe üzerinden tahlil etmek istiyoruz:

05-11. 10. 2009 tarihleri arasinda Mekke'de "31. Uluslararasi Kral „Abdu'l-,Azłz Kur'ân-1 Kerîm'in Hıfzı, Tilâveti ve Tefsiri Yarışması” yapıldı. 115 ülkeden 174 yarışmacının katıldığı müsabaka 7 gün sürdü. Dünyada şu anda ilgili hükümetlerce resmi olarak Mushaf'1 basılan ve takip edilen dört rivayetin (" Êøn, Verş, DørPve i afò) pratik uygulamaları dikkat çekiciydi. Her bir yarışmacı tercih ettiği rivayetin kurallarıyla değerlendirildi. Japon, Kanadalı ya da Koreli hafızların Kur'an okuyuşlarını dinlemek tabii ki heyecan vericiydi. Yarışmada 5 kategori vard1. Bunlar: "Tefsiriyle birlikte 30 cüz’ün hıfzı", “Tefsirsiz 30 cüz’ün hıfzı”, “20 cüz’ün hıfzı”, “10 cüz’ün hıfzı" ve "5 cüz'ün hıfzı". Her yarışmacıya 5 soru soruldu. Her bir soruda

kitap yazabileceklerini muhtelif sert ifadelerle beyan etmektedir. Bu güne kadar da bu meydan okumaya ciddiye alınabilir somut bir cevap verilebildiği görülmemiştir.

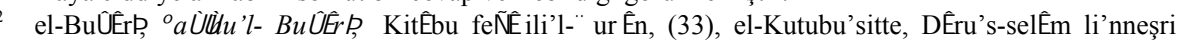
ve't-tevzÙ Riyad 2008, s.437.

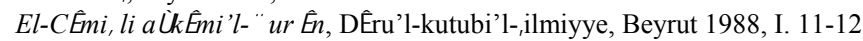

A.g.e., I. 15 
ezberden 30 satır okumaları istendi. Sorular, yarışmacı yarışma kürsüsüne çıktığında bilgisayar aracılığıyla tespit edildi. İlk kategoride puanlar; tefsir: 20, hifz: 50, tilavet: 10 ve tecvid: 20 puan sistemi esas alınarak verildi. Diğer kategorilerdeki yarışmacılar ise, hıfz: 50, tilavet: 20 ve tecvid: 30 puanlama sistemi üzerinden değerlendirildi. Yarışmaya Türkiye'den üç yarışmacı katıldı. Yarışmacılarımız, "Tefsirsiz 30 cüz'ün hıfzı", "20 cüz'ün hıfzı" ve "10 cüz'ün hıfzı" kategorilerinde yarıştılar. Altısı Suudi Arabistan'dan altısı da diğer Müslüman ülkelerden olmak üzere toplam 12 jüri üyesi iki ayrı komisyon oluşturdu. Bu yarışmada Türkiye Cumhuriyeti'ni temsil eden jüri üyesi olarak yerine getirmeye çalıştığım görev sırasında -bilindik komisyon üyeliğinin yanısıra- farklı kültürlerin Kur'an kıraatine (okumaya) bakışlarını anlamaya çalıştım. Daha da önemlisi, ülkemizdeki Kur'an eğitiminin diğer Müslüman ülkelerden nasıl göründüğüne dair dikkate almamı gerektiğine inandığım değerlendirmelere şahit oldum.

\section{Mahallî Okuyuş}

Dünyanın hemen her bölgesinden gelen yarışmacıların kıraatleri (okuyuşları) arasında tabii ki nitelik farklılıkları vardı. Ancak Türk yarışmacıların kıraatleri ile diğer birçok ülke hafizlarının kıraatleri arasında neredeyse mahiyet farkı gözlenmişti: Türk hafızlar açıkça kendileri dışındaki dünyayı umursamadan mahalli "ağız" ile Kur'an okumuştu. Sonuçta, benim yer aldığım komisyonun başkanı, aynı komisyonun önünde yarışan her iki Türk yarışmacıyı da yetersiz bularak kıraatlerini sonlandırmıştır. Maalesef Türk yarışmacılar, benzer gerekçelerle kıraatleri sonlandırılan az sayıdaki yarışmacı arasında kalmışlardı. Bu durumun beni mahcup ettiğini itiraf etmeliyim. Aynı komisyonda yarışan Mısırlı yarışmacının tecvid kurallarına ve gerekli dudak hareketlerine yeterli özeni göstermediği için Türkiyeli yarışmacılar gibi oldukça düşük puan alması, komisyon başkanı ve üyelerinin siyasi ya da milliyete dayalı kaygılarla değerlendirme yapmadıklarını ispat ediyordu.

Burada, Medine-i Münevvere Harem-i Şerifi emekli imamı ve şu anda k1raat konusunda Suudi Arabistan'daki en önemli otoritelerden sayıldığı için

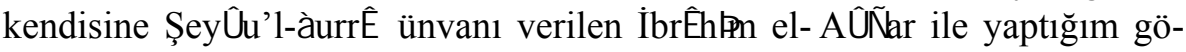
rüşmenin önemli noktalarına temas etmek istiyorum: Öncelikle el-[A Û̃̂̃ 15 senedir Türkiye'ye gelip gittiğini Sultan Ahmed ve Fatih camisinin imamlarını tanıdığını hatta merhum Abdurrahman Gürses Hoca ile zamanında çok iyi ahbab olduklarını, Gürses Hoca'nın umreye geldiğinde Medine'de kendi evinde kaldığını söyledi. el-[Â̂Nân hangi gerekçelerle Türklerin dünyadan farklı Kur'an okumaya çalıştıklarını bildiğini, ancak bu gerekçelerin doğru olmadığını belirtti. Bütün açıklığıyla konuyu irdeleyebilmek için, Türkiye'de 
çokça söylenen "Türk okuyuş tarzının kıraat kitapları tarafindan desteklendiği, Arap okuyuş biçiminin ise bu kitapları dikkate almadığı" yolundaki iddiay ${ }^{5}$ hatırlattığımda el-[ÂŨNar'ın bu iddiadan haberdar olduğunu gördüm. Daha sonra konuşmaya örnek üzerinden devam etmek isteyerek tecvid kurallarından "1àlB̂B" konusunu gündeme getirdim. Çünkü özellikle Arap dünyas1 ile Türk okuyuşu arasındaki dikkat çekici farklılıklardan birisi bu konu ile ilgilidir. Türkler ağızlarını tam kapatarak, Arapların önemli bir kısmı ağızlarını kapatmaksızın dudakları arasında küçük bir boşluk bırakarak "ıàlı̂" kaidesini uygulamaktadırlar. Böylece, her iki uygulama arasında bariz bir ses ayırımı ortaya çıkmaktadır. Bu konuyu konuştuğumuz sırada el-@Â̂̃̃ar, “1àlÊ" kaidesinin Türklerin de el kitabı olan İbnu'l-Cezer円nin (833/1429) en-Neşr fi'l-àırÊE Gti'l-aşr isimli kitabındaki tarifini ${ }^{6}$ hatırlattı: Buna göre

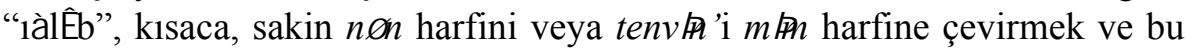
$m \mathrm{H} n$ harfini $b \hat{\mathrm{E}}$ harfinden önce ğunne ile 1 ÛfÊ $\sqsupset$ yapmaktır. Bu tarife uygun hareket etmek isteyenler "1àl|̂̉"1 uygularken "1ÛfÊ da yapmak gerektiği ve "1ÛfÊ]ağız kapalı iken yapılamayacağı için ağızlarını -el-@ÂŨNar'ın ifadesiyle- iki dudak arasına yatay vaziyette bir defter sayfası sığacak kadar açık bırakmaktaydılar. Yani, ıàl|̂̉ örneğinde "Kitab" Türkiye'deki iddiaların aksine Türk okuyuşunu desteklemiyordu. ${ }^{7}$

el-₫Â̂Nâr konuyla ilgili en büyük sorunun usul hatasından kaynakland1ğını belirtti. Ona göre yanlış olan, Türkler'in kıraat ilmini kitaptan öğrenebileceklerini zannetmeleriydi. Oysa kıraat, esasta "ses"e dayalı bir ilim olduğu için ve "ses" gözle okuyarak değil; ancak kulakla duyularak hakkıyla kavranabileceği için İslâmî ilimler içinde kıraat ilminin esas kaynağı kitap yerine "hoca" idi. Kitap ancak yardımcı bir kaynak gibi değerlendirilmeliydi. Nitekim İslâmî ilimler geleneği içinde çıkan fem-i muhsin (uzman ağzı) tabiri bütün bunları özetliyordu. Daha sonra el-[Â̂̃Nar söylediklerini doğrulamak için bana şu soruyu sordu: 'Eğer kitap belirleyici ise, Türkiye'de okutulan kıraat kitaplarının hemen hepsi çok daha yoğun bir şekilde Arap aleminde ve bütün dünyada okutulduğu halde neden mahiyetleri farklı okuyuşlar ortaya çıkıyor?' Ben susarken el-[Â̂̃̂̃ar cevabı kendisi verdi ve belirleyicinin kitap

\footnotetext{
Mesela bkz. Ali Rıza Sağman, Mevlid Nasıl Okunur? Ve Mevlidhanlar, Fakülteler Matbaası, İstanbul 1951, s. 45 (28 numaralı dipnot); İlâveli Yeni Sağman Tecvidi, Ahmed Said Matbaası, İstanbul 1958, s. 22 (26 numaralı dipnot).

Mała,atu't-tevflà, Dımeșk 1345, II. 125

İsmail Karaçam, "ıàl|̂̂"ın yukarıdaki tarifini verdikten sonra şu açıklamayı yapmaktadır: "Memleketimizdeki hafızların okuyuşunda ıklâbın birinci kısmı olan kalb işi yapılıyorsa da, ekseriyet ikinci kısmı olan ihfâyı terk etmektedirler”. Bkz. İsmail Karaçam, Kur'ân-ı Kerîm 'in Faziletleri ve Okunma kaideleri, Marmara Üniversitesi İlahiyat Fakültesi Vakfı Yayınları, İstanbul 2009, 303 (915 numaralı dipnot). Karaçam, şaşırtıcı bir şekilde, tarife uymayan uygulamamızı ne gerekçelendirmekte ne de eleştirmektedir. O, sadece bir durum tespiti yapmaktadır.
} 
değil “hoca" olduğunu söyledi. el-[A Û̃̂ar'a göre Türkler kitab1 asıl kaynak zannettikleri için kıraat ilminin önceliklerini belirlerken de yanılmaktaydılar. Söz gelimi, herhangi bir harfin mahrecini bulmak konusunda kitaptan okuduklarını ve sübjektif algılarını -bir türlü tatmin olamadıkları için- tekellüf noktasına vardırırken, ${ }^{8}$ Arap dilinin temel özelliklerini ikinci plana atabiliyorlardı. Mesela, Arapçada "ü" sesi, "ü-u" arası bir ses ve hatta "ü" sesinin hiç bir tonu yer almadığı halde Türkler Arapça olan Kur'an'ı Arap kulağını rahatsız edecek bu seslerle okumaktan hiç rahatsızlık duymamaktalardı. elA Â̂Nar, kalın harflerin "ötre" haliyle ince harflerin "ötre" halinin tabii ki farklı olduğunu ve bu farkın Arap dilinde yer alan "u" sesinin tonlarıyla gösterilmesi gerektiğini belirtti.

Tam bu noktada fem-i muhsin ${ }^{9}$ kimdir? Sorusu gündeme gelmektedir. Acaba Arap dilinin ses özellikleri ile ana dili Arapça olan kıraat uzmanlarını dikkate almayarak, bütün ömrünü kıraat ilmine ve talebe yetiştirmeye adamak, kıraat ilmini, kitaptan ya da kitaptan öğrenen hocadan almak ve zincirleme bir şekilde yüzyıllar öncesine dayanan bu mahalli geleneğin bu günkü temsilcisi/muallimi olmak, -hissi değerlendirmeleri bir tarafa bırakırsakkişiyi fem-i muhsin yapar mı? Acaba İngilizce'nin fonetiği konusunda, Pakistan'da bütün ömrünü İngilizce eğitimine adamış mahalli lehçe ile İngilizce konuşan ve öğreten bir eğitmen, Oxford İngilizcesi konuşan ve öğreten bir İngiliz eğitmene hatta bir lise öğrencisine tercih edilebilir mi?

Milletimize, neden aslî dili Arapça olan insanların öncülük ettiği evrensel kabul gören kıraat ile değil de mahalli Türk kıraatiyle Kur'an öğretiyoruz? $\mathrm{Bu}$ konuda aklıma gelen iki hususu bütün açıklığıyla gündeme getirmek istiyorum:

Ülkemizde "SubÙ̂Eneke duasını ya da $F \hat{E} i$ il̀ benzeri kalıplardaki sık duyduğumuz ifadeler, ilk bakışta ilgili "Hoca"yı ya da eğitim sürecini övüyor gibi görünse de aslında bu “tekellüf'ü işaret etmektedir.

9 Bu makaleyi hazırlarken görüşlerine başvurduğum konunun uzmanı Mustafa Akdemir'in konuyla ilgili açıklamaları şunlardır: " İbnu'l- Cezeri'nin kullandığı femu'l-mu Ùsin (bkz.İbnu'l-Cezerb, en-Neşr

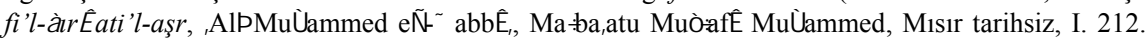
Bu kitabın 2. dipnotta kullanılan baskısının bir kısmına ulaşamadığımız için burada ayrı bir basımından yararlandık) tabiri 'doğru teleffuzu, güzel ifadeyi ve edayı gösteren ağız' demektir. Bu terimi daha çok biz kullanmaktayız. Arapça olduğu halde, Araplarda bu terimin kullanımı yaygın değildir. Bunun

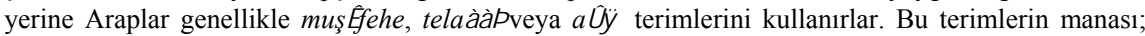
'Kur'an-1 Kerim'i, ilk öğreticiye bağlayan zincire halka olmuş, indirildiği şekilde okuma gayreti ve hassasiyeti ile, lafızlarını en doğru ve fasih bir şekilde teleffuz etme ve öğretme maharetini kazanmış

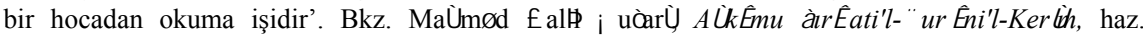
MuÜhmmed 1/alùh Bil|̂, el-Mektebetü'l-Mekkiyye 1996, s.18-19. Dolayisiyla bu terimlerde femu'l$m u$ Ùsin manasına ilave olarak, ilmin ve telaffuz keyfiyetinin, teselsülen ilk kaynağa bağlanması manası da vardır. Kur'an öğreniminin başka bir vasıtaya ihtiyaç duymadan elde edilebileceği bu yol, denenmiş bir usulün mahsulü ve hala da alternatifsiz en ideal yoldur". 


\section{a. Siyâsî Sebep}

Dünya küçülmeden ve küreselleşme başlamadan önce her Müslüman millet mahalli kıraatleriyle Kur'an okuyordu. Biz de Osmanlı İmparatorluğu döneminde aynen şimdiki gibi mahalli Türk ağzıyla Kur'an okuyorduk. O zamanlar, herhangi bir bölgedeki sıradan halk kitlelerinin başka bir bölgenin mahallî kıraatine vukûfiyeti tabii ki kolay olmuyordu. Belki de her millet, bütün Müslümanların kendileri gibi Kur'an okuduğunu düşünüyordu. Farklılıklardan haberdar olan elit kesimin ise iki açıdan herhangi bir adım atmasına gerek yoktu: birincisi, böyle bir sorunun varlığı çok geniş kesimlere ancak teorik olarak gösterilebilirdi. Oysa halk için, pratik hayata yansımayan böyle teorik bir sorunun çözümünü önemsemek en iyimser ifade ile iğreti kalırdı. İkinci olarak, teknik şartlar sebebiyle bu soruna anlamlı bir çözüm üretme şansı yoktu. Sorun, küreselleşme ile birlikte, basın-yayın organlarının ve milletler arasındaki doğrudan etkileşimlerin etkisiyle, sıradan halk tarafindan bile yoğun olarak hissedilmiştir. Böylece sorgulamalar ve sonuçta kargaşa kaçınılmaz olmuştur. Artık her millet diğerinin Kur'an okuyuş biçiminden haberdardır.

Küreselleşme ile birlikte Türkiye dışındaki bütün Müslüman ülkeler Kur'an'ın Arapça olmasını dikkate alarak makulden yana bir tutum belirlediler: Türkçe bir metni Türklerin, İngilizce bir metni İngilizlerin, Almanca bir metni Almanların, Japonca bir metni Japonların okuyuş biçimi, doğru okuyuşu tespit ederken tabiî ki en belirleyici öğe olarak kabul görmelidir. Kur'an kıraatinde Arap'ın ağzını ve kulağını hiçe sayarak "ben bildiğimi okurum" mantığıyla hareket etmek, fanteziden öte ne ilmîdir ne de evrensel bir değer taşır. Nitekim Arap dünyasıyla siyasi ve mezhebî açılardan sürekli çatışma halindeki İran bile küreselleşme sonrası derhal Arabî tarz Kur'an tedrisine geçmiştir. Bu gün, Kur'an okurken Arap tarzından farklı bir okuyuşu sürdüren Müslüman ülkeler, ya kısıtlı imkânları sebebiyle bu okuyuş tarzını geniş kitlelere öğretemeyen, ya da Türkiye'nin etkisiyle mahalli Türk kıraatini tercih eden ülkelerdir. O halde, Türkiye, başta Türkiye Cumhuriyeti Diyanet İşleri Başkanlığı olmak üzere neden kendi mahalli kıraatini esas alarak Kur'an öğretiyor? Neden özellikle Kur'an kuraatini, buraya kadar üzerinde durmaya çalıştığımız akli çıkarımların istisnası kabul ediyor? Neden bizler bazı Türk kıraat uzmanlarının en doğru Kur'an okuyuş şeklinin Araplarınki değil de Türklerinki olduğunu söyleyebilecek kadar ileri gitmelerinden rahatsiz olmuyor hatta haz alabiliyoruz? Herhalde bu sorularm cevapları doğrudan Türkiye'nin geçmişi ile ilgilidir. Yüzyıllar boyunca Müslümanlara önderlik yaparak bütün insanlık tarihinin önemli medeniyetlerinden birini inşa eden Türkler, önderliklerini hiç olmazsa Kur'an'1 öğrenen değil de öğreten sıfatıyla devam ettirmek istiyorlar. Böylece, salt ilmî bir konuda siyâsî bir duruş tercih ettikleri için mahallîlikten kurtulamıyorlar. 
Ancak küreselleşmenin bu kadar etkili olduğu dünyamızda, sadece siyâsî mülahazaların etkisiyle desteklenen mahalli Türk okuyuşunun, ilmî ve aklî yaklaşımın açık desteğini alan evrensel Arabî Kur'an kıraati karşısında ne kadar şansı olabilir ki? Herhalde, bu şekilde evrensel kıraate geçiş süreci en fazla geciktirilebilir.

Siyasi bakışın tuhaf tercihlere sebep olduğu yegâne ülke Türkiye değildir. Burada hem Kabe hem de Medine Harem Camisinde bile sıkça karşılaşılan bir gariplikten bahsetmek istiyorum: İslam'in en kutsal mabedleri olarak kabul gören bu iki mescitte birer gün geçirdiğinizi varsayalım. Herhangi bir vaktin ezanında ya da namazında, müezzinin ve imamın, kıraat ilminin inceliklerine vakıf insanların dahi kusur bulamayacağı yüksek düzeydeki okuyuşlarına ve nihai derecede etkili ses-sedalarına tanık olabilirsiniz. Ancak, aynı tecrübeyi mütaakip namaz vaktinde bir kez daha yaşamayı beklerken hayal kırıklığına uğrayabilirsiniz. Çünkü bu defa da bahsi geçen hemen her bakımdan gerçekten "kötü” iki okuyuşla karşılaşırsınız. Sizi şaşırtan, Suudi Arabistan'ın bilindik dînî siyasetindeki "Ses, sedâ ve kırâat ilminin incelikleri metnin önüne geçmemelidir" ilkesinin günümüze uymadığını açıkça müşahede ettiğiniz yorumu ve bu yoruma uygun tatbikatıdır. Bu siyaset, yukarıda mahalli okuyuşumuza yönelttiği eleştirilerini arz etmeye çalıştığım İbrÊhPn el-[Â̂̃̂̃ar'1 düşündürücü/gülünç bir gerekçeyle zorunlu emekliliğe sevk edebilmiştir: Medine Harem Camisi imamı el-[Â̂̃Nar'ın en fazla dikkat çeken suçu! namaz kıldırırken Kur'an'1 makamlı okumasıydı. Yani söz konusu siyaset aslında mahareti ve başarıyı cezalandırmıştır.

Diğer bir örnek Suudi Arabistan dışındaki çoğu Arap ülkesinin rağbet ettiği Kur'an-1 Kerim'i tahkik usulüyle güzel okuma yarışmalarıdır. Son yıllarda ülkemizi de sık sık ziyaret eden bazı "Dünya birincileri”nin, ülkemizde gerekli Kur'an eğitimini almış bir İmam-Hatip öğrencisi tarafından bile rahatlıkla tespit edilebilecek tecvid hatalarına tanıklık etmekte ve şaşırmaktayız. Bu yarışmaların düzenleyicileri ve hakemleri, herhalde, seçtikleri birincilerin dünyanın çeşitli ülkelerini ziyaret edeceklerini, fevkalade etkili sesleri aracılığıyla Müslümanların özgüvenlerini artıracaklarını, gayri Müslimlerin ilgisini de Kur'an'a celbedeceklerini düşünmektedirler. Bu yar1-siyâsî ve gayri ilmî tasavvur yukarıda sözünü ettiğimiz garâbetin ortaya çıkmasına sebep olmaktadır. Öyle ki, seçilen bazı "Dünya birincileri”ne, yarışmaları düzenleyen ülkelerin resmî eğitim kurumlarında bile Kur'an okutmanlığı yaptırılmayacağından şüphe duymuyorum.

\section{b. Psikolojik Sebep}

Mahalli Türk okuyuşu-Arabî evrensel okuyuş ikileminde siyâsî sebepten kısmen bağımsız olan bir başka unsur da gözlenmektedir. Türkiye'de yaşa- 
yan insanlar çoğu evrensel değere Türkiye'nin şartlarının özel ya da farklı olduğu gerekçesiyle öznel bir içerik kazandırmaya çalışmaktadırlar. Genel olarak evrensel yaklaşımlardan; mesela, evrensel "üniversite eğitimi" ve "yabancı dil öğrenimi" tasavvurlarından uzaklaşarak "bize göre" tanımlar icat etmeye çalışmanın ne denli gerilimlere sebep olduğunu defalarca tecrübe etmemize rağmen bir türlü evrensel olana uygun hareket edememekteyiz. Mahalli Türk kıraati ya da "bize göre Arapça eğitimi” konularındaki ısrar, bu toplumsal eğilimin mütedeyyin kesimdeki tezahürleridir. Ankara Üniversitesi İlahiyat Fakültesinde görev yapan bir Arapça hocamızı, 'Arapça konuşma, dinlediğini anlama ve kompozisyon yazmanın' önemine ikna edemediğimi hatırlıyorum. Hocamız, her dil için evrensel kabul gören dil öğretim mant1ğını; öğrencinin dilin dört unsuru ile (okuma, anlama, konuşma, yazma) eş zamanlı olarak tanıştırılması gerektiğini hatırlattığımda 'bizim şartlarımızın ve Arapçanın’ özel olduğunu söylemişti! Ona göre öğrencinin klasik kaynakları okuduğunda anlaması yeterliydi! Hocamız, Almanya'da bir sene Arapça eğitimi alan Alman bir üniversite öğrencisinin bile klasik kaynaklardan yararlanabilme ve dilin zikri geçen dört unsurunu kullanabilme melekelerini ileri derecede olmasa da- kesb edebildiğini söylediğimde dahi ikna olmadi. Çünkü hocamı, Türkiye'de on seneden fazla Arapça dersi gördüğü halde Arapçayı en basit ihtiyaçlarını gidermek için bile kullanamayan geniş bir kitlenin varlığından rahatsız olmuyordu!

Neden özellikle çok önemli konularda evrensel tercihleri tehlikeli ya da yanlış buluyoruz? Acaba yaşadığımız "zor" coğrafya mı bizleri bu yanılsamaya sürüklemektedir? Dünyayı yöneten Batı ile ait olduğumuz Doğu arasındaki ayırım noktasında yaşadığımız için mi sanal tehdit algılarından muzdaripiz? $\mathrm{Bu}$ algılar mı bizi savunmacı ve müzmin kararsız yaparak hemen her değeri mahallileştirmeye sevk ediyor? "Evrensel", onu sürekli avucumuzun içinde tutamayacağımız, dolayısıyla ona anında müdahale edemeyeceğimiz için mi korkutuyor? "Evrensel”in kimliğimizden bir şeyleri alıp götüreceğini mi düşünüyoruz? Mahalli Kur'an kıraatini terk edersek asli Kur'an okuyuşu mu kaybolur? Ya da Halkımız Kur'an'dan mı uzaklaşır? Şüphesiz benzer soruların sayısı artırılabilir. Ancak bu noktada en hayati soruyu atlamamalıyız: Büyük oranda, sanal tehdit algıları yüzünden müptelası olduğumuz "mahallilik" tutkusunun peşinden daha ne kadar gidebiliriz?

Kur'an kıraatinde, mahalli okuyuşların zenginlik kaynağı olduğunu düşünerek her milletin kendi mahalli okuyuşunu sürdürmesi gerektiği iddia edilebilir mi? Milletler, gerçekte kendilerine ait olan değerler üzerinde belirleyici olabilirler. Türk dilinin ve fonetiğinin kuralları Türkler, Arap dilinin ve fonetiğinin kuralları da Araplar tarafından belirlenmelidir. Bu yaklaşım, menşe itibari ile bize yabancı/başkasına ait bir değer de olsa, Kur'an kıraatinin bize 
özgü mahalli ifade biçimlerini değersizleştirmez. Mahalli Kur'an okuyuşumuz "biz yüzyıllar boyunca Kur'an'ı böyle okuduk" anlamına gelen ve artık mümkün olduğunca akademisyenlerin çalışmalarına konu edilerek koruma altına alınması gereken kültürel bir zenginliktir. Yoksa uluslar arası her türlü bilgi alış-verişinin nihai derecede kolaylaştığı günümüzde, Arap ülkelerine coğrafi olarak da bu kadar yakınken, milyonlarca Türk vatandaşına mahalli Türk kıraatini esas alarak Kur'an öğretmeye devam etmek yanlıştır. Küreselleşmenin akıl almaz bir hızla devam ettiği dünyamızda bu yanlış tercihte 1srar etmek her gün biraz daha zorlaşacak ve anlamını yitirecektir. Diğer taraftan bu 1srar, evrensel okuyuşun doğal çekiciliğine kapılan, ancak doğru kıraat pratiğinin asgari seviyesini dahî yakalayamayan hatırı sayılır sayıdaki bir kesimi, evrensel kıraat tarzını taklit etmek seçeneğiyle; üstelik yalnızca kaset ve CD'lerle baş başa bıraktığı için ülkemizdeki Kur'an eğitimine zaten yeterince hasar vermiştir.

\section{GENEL DEĞERLENDİRME VE TEKLIFLER}

Milli Eğitim Bakanlığının ve Diyanet İşleri Başkanlığının düzenledikleri "Güzel Kur'an-1 Kerim Okuma", "Güzel Ezan Okuma" ve "Hafizlık" yarışmalarının "bölge" ve "Türkiye" finallerinde son dört-beş senedir jüri üyeliği yapmaktayım. Aynı dönemde Ankara Üniversitesi İlahiyat Fakültesindeki tefsir derslerinin yanı sıra yoğun olarak Kur'an-1 Kerim dersleri de verdim. Böylece öteden beri var olduğunu bildiğim bir sorunu daha yakından görme imkânı elde ettim. Öyle ki, Türkiye finallerinde jüri üyeleri tarafından puan kırma sebebi olarak görülen bazı ağız-dudak hareketlerinin ve ses kullanımlarının, Suudi Arabistan'da gerçekleştirilen Dünya hafızlık yarışmasındaki jüri üyeleri tarafindan asgari şart olarak arandığını, hatta olumlu puan verilerek ödüllendirildiğini bile yakinen müşahede ettim.

Türkiye'deki ilgili hemen her yarışma öncesi ya da sonrasında "Arap gibi Kur'an okuyanların puanlarının kırılacağına" dair yargılarla bizzat karşılaşmaktayım. Burada, Arapça bir metni Arap gibi okumanın övgü değil yergi vesilesi olarak görülebildiğine özellikle dikkat çekmek istiyorum!

Halkımız tarafından Kur'an'ın gerek yüzünden okunmasının gerekse hıfzının çok önemsendiği ve Diyanet İşleri Başkanlığının bütün gücüyle ihtiyac1 karşılamaya çalıştığ gözlenmektedir. Ancak, belki de bütün dünyada bu konuda en fazla emek harcayan ülkeler arasında yer almamıza rağmen, çalışmaların mahalli Türk okuyuşu esas alınarak yürütülmesi, bütün bu emeklerin Türkiye dışında takdir görmesini engellemektedir. Hatta söz konusu uluslar arası yarışmada, kasten mahalli bir okuyuşu tercih ettiğimizden ha- 
bersiz olan insanların "Türklerin ağız ve boğaz yapılarının Kur'an okumaya elverişli olmadığı" yolundaki değerlendirmelerine üzülerek tanıklık ettim. ${ }^{10}$

Türkiye'deki bütün bu gayretlerle Türkiye dışında aynı alanda gerçekleştirilen faaliyetler arasında çok önemli bir kaç fark daha bulunmaktadır. Öncelikle, Türkiye Kur'an'ın manasını hiç anlamayan hafızlar yetiştirmektedir. Konuştuğum birçok ülke temsilcisi Kur'an eğitimini mümkün olduğunca Kur'an'ı anlayacak kadar bir Arapça öğretimi ile birlikte yürütmeye çalıştıklarını belirttiler. Ülkemizde Kur'an'1 hiç anlamadan ezberleyen binlerce hafızın bulunduğunu izah etmekte zaman zaman zorlandığımı itiraf etmeliyim. Türk halkının, Kur'an'1 okumaya ve ezberlemeye bu kadar ehemmiyet verdiği ve mesai harcadığ sorun etmemesi ciddi bir bilinçlenme ihtiyacının açık göstergesidir. ${ }^{11}$ Diğer taraftan, Mustafa Akdemir'in hafizlık geleneğimize yönelttiği şu eleştirilere hak vermemek mümkün değildir:

"Hafızlarımızın sayısı ve ezber kuvveti ile övünebiliriz belki ama şu donanım zafiyetlerini göz ardı etmemeliyiz:

1. Bizim hafızlarımızın çoğu 114 sure tertibini bilmez.

2. Hafızlarımıza "Şu surenin başından başla!" dendiğinde; bocalar, ilk ayetin hatırlatılmasını bekler.

3. Hafizlarımız şaşırdığı vakit, kendilerine "Ayeti baştan al!” dendiğinde; zorlanır, hatırlatılmasını ister.

4. Hafızlarımızdan durak ve ayet sonlarında geçmeleri istendiğinde; çoğunlukla son harekeyi verip geçemezler. Çünkü ezberlerini buralarda hep durarak yapmışlardır, kimse onlara geçerek de okuyabilmeleri gerektiğini söylememiștir. 6236 ayet sonu ve içerideki vakıf mahallerini hesapladığınızda, kendisi ile iftihar ettiğimiz hafızlarımızın ezberlerinde binlerce harekenin eksik olduğunu görürüz."

Diyanet İşleri Başkanlığının öncülük edeceği uluslar arası geniş kapsamlı bir çalıştay tertip edilerek bütün bu sorunların yerli-yabancı uzmanlarla müzakeresi ve ortaya çıkacak bilimsel sonuçların Başkanlıkça dikkate alınması yararlı olacaktır. Yine Türkiye'nin öteden beri tertip ettiği ulusal Kur'an yarışmalarının yanı sıra uluslar arası yarışmalara ağırlık vermesi, bütün bu sorunlarla doğrudan yüzleşmesine ve çözümler üretmesine yardım edecektir. Gerek İlahiyat Fakülteleri, gerekse Diyanet İşleri Başkanlığı bünyesinde

${ }^{10}$ Mahalli okuyuşumuz yalnızca Arapların ya da Müslümanların dikkatini çekmemektedir. Oryantalist Andrew Rippin Manisa'da dinlediği sabah ezanları için "Turkish-Pronounced Arabic" (Arapça'nın Türkçe telaffuzu) tanımlamasıyla bu mahalliliğe vurgu yapmaktadır. Bkz. Andrew Rippin, Muslims, Routledge, Londra-Newyork 1993, II. 1

11 Kıraat ilminin önde gelen isimlerinden İbnu'l-BennÊ](1117/1705) anlamı esas almayan Kur'an okuyuşunu çok ağır bir dille eleştirmektedir. Bkz. İbnu'l-BennÊ, Kit Êtbu it

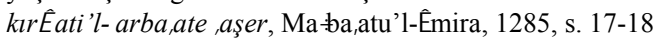


sürdürülen Kur'an eğitiminde fem-i muhsin hüviyetini haiz Arap eğitmenlerden yararlanılması sorunun çözümüne en anlamlı/makul/bilimsel katkıyı sunacaktır. Aslında bu, ne hayâlî ne de nevzuhur bir tekliftir. Özgüven sorunu hiç yaşamadığımız ve konuya salt ilmî bakabildiğimiz asırlar, benzer uygulamalara yabancı değildir:

"Kânûnî Sultan Süleyman, Nâsıruddîn et-Tablâvî (ö.966/1558)'nin damadı olan Ahmed el-Mesyerî (ö.1006/1597)'yi Misır'dan İstanbul'a davet etmiş ve bu iş için de sadrazam Sokullu Mehmet Paşa (ö.987/1579)'y1 görevlendirmiştir. Sokullu bu zâta Reîsü'l-Kurrâ' unvanı vererek Eyüp Sultan Camii'nde imâmete tayin etmiş ve cami yanındaki Dâru'l-Kurrâ'da müderrislikle görevlendirmiştir. Eserleri ve yetiştirdikleri talebelerle ünlü Evliyâ Muhammed Efendî (ö.1044/1634), Muhammed b. Ahmed el-'Avfî (ö. 1050/1640) ve Dersiâm Muhammed Efendî (ö. 1054/1644) gibi Osmanlı kıraat alimleri hep onun rahle-i tedrîsinde yetişmişlerdir. Yine Köprülü Fazıl Mustafa Paşa Mısır'da vali olduğu sırada tanıdığı büyük kıraat alimi Ali elMensûrî (ö.1134/1721)'yi sadrazam olunca İstanbul'a davet etmiş ve Çemberlitaş'ta bulunan Köprülü Dâru'l-Hadîsi'nde ve Kütüphanesi'nde görevlendirmiştir." ${ }^{2}$

$\mathrm{Bu}$ makalede de 1srarla üzerinde durulduğu gibi, mademki Kur'an Arapça'dır, o halde fem-i muhsin, kıraat ilminin gereklerini yerine getiren bir Arap ya da onu aratmayacak kadar ona benzeyendir. Kur'ân "fem-i muhsin"den öğrenilmelidir. Ülkemizin ilgili kurumları, bilimin ve aklın onaylayacağ sunduğu imkânlardan yararlanarak Arap hafizların okuyuşlarını taklit etmeye dayalı yaygın, ancak kıraat eğitiminin fem-i muhsin merkezli tabiatıyla mütenasip olmayan, yanlış uygulamaların da önüne geçilmiş olacaktır.

\section{Kaynakça}

Akdemir, Mustafa, tah. Zubdetu'l-,irfÊEn, „Abdu'l-fettề PaluvÙ Marmara Üniversitesi Sosyal Bilimler Enstitüsü, yayınlanmamış doktora tezi, İstanbul 1999.

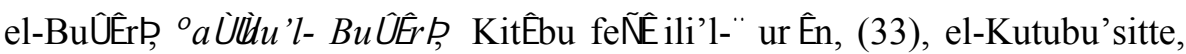
DÊru's-selÊm li'nneşri ve’t-tevzપ̣ Riyad 2008.

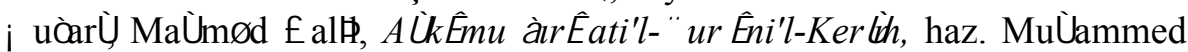
1/alù Bil|̂, el-Mektebetü'l-Mekkiyye 1996.

12 Mustafa Akdemir, tah. Zubdetu'l-,irf伦, ,Abdu'l-fettề PaluvÙ Marmara Üniversitesi Sosyal Bilimler Enstitüsü, yayınlanmamış doktora tezi, İstanbul 1999, (Türkçe Bölümü) s.27 


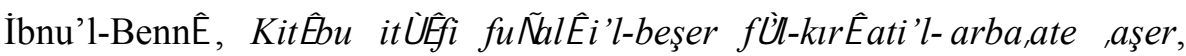
Ma ba,atu'l-Êmira, 1285.

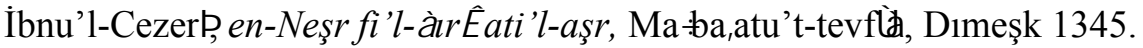

Karaçam İsmail, Kur'ân-ı Kerîm'in Faziletleri ve Okunma kaideleri, Marmara Üniversitesi İlahiyat Fakültesi Vakfı Yayınları, İstanbul 2009.

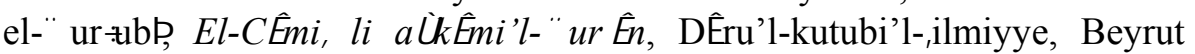
1988.

Rippin, Andrew, Muslims, Routledge, Londra-Newyork 1993.

Sağman, Ali Rıza, Mevlid Nasıl Okunur? Ve Mevlidhanlar, Fakülteler Matbaası, İstanbul 1951.

Ilâveli Yeni Sağman Tecvidi, Ahmed Said Matbaası, İstanbul 1958. 